Tohoku J. exp. Med., 1982, 138, 319-328

\title{
Insulin-Receptor Autoantibody Detected by the Human Placental Membrane Method: Six Patients with Insulin-Receptor Autoantibody in Japan
}

\author{
Yasue Omori, Satomi Minei, Machiko Saito and Yukimasa \\ Hirata \\ Diabetes Center, Tokyo Women's Medical College, Shinjukuku, \\ Tokyo 162
}

\begin{abstract}
Omori, Y., Minei, S., Saito, M. and Hirata, Y. Insulin-Receptor Autoantibody Detected by the Human Placental Membrane Method: Six Patients with InsulinReceptor Autoantibody in Japan. Tohoku J. exp. Med., 1982, 138 (3), 319-328 Insulin-receptor antibodies were detected in six patients out of 61 diabetics from all over Japan during 1975 to 1979 using the human placental membrane method. These 61 patients were divided into three categories: (1) Those whose diabetes control needed more than 80 units of insulin a day; $(2)$ those whose fasting IRI was higher than $50 \mu \mathrm{U} / \mathrm{ml}$ even with glucose intolerance; and (3) those who had hypoglycemia of unknown origin. Controls consisted of 11 serum samples from 11 healthy women and six diabetics treated with insulin and thus having insulin antibodies in their sera. The sera from healthy subjects did not suppress ${ }^{125} \mathrm{I}$ insulin binding with human placental membrane in either the direct or the preincubation method. ${ }^{125}$ I-insulin binding in the direct method was markedly suppressed, however, by the sera of insulin-treated diabetics, although no such suppression was observed with the preincubation method. In six of the 61 subjects (two males and four females), inhibition of binding was proved by both direct and preincubation methods for the protein fraction of the sera, particularly for the IgG fraction in five cases. Three of the six had Sjögren syndrome; one of these also had acanthosis nigricans. Four of the six showed insulin resistance, and two did not. A follow-up showed that antibodies decreased relatively quickly in three of the six cases, with the degree of inhibition paralleling patients' clinical courses. insulin-receptor antibodies; human placental membrane; acanthosis nigricans; insulin resistance; hypoglycemia
\end{abstract}

In 1976, Kahn and his co-workers reported that some of the diabetics with marked resistance to exogenous insulin had insulin-receptor antibodies in their sera, and that these cases were associated with acanthosis nigricans. They studied the antibody using circulating cells such as monocytes and erythrocytes, and cultured lymphocytes. We have reported a method of checking the insulinreceptor antibodies using a pellet of insulin receptor extracted from human placental membrane (Omori and Hirata 1976). This method is particularly useful for the detection of insulin-receptor antibodies, since human placenta can be easily obtained.

Received for publication, March 8, 1982. 
Using this method, from September 1975 to October 1979, we found six patients with insulin-receptor antibodies among subjects with hypoglycemia of unknown origin, those with serum IRI levels high in the face of hyperglycemia, and those whose diabetes control needed more than 80 units of insulin a day.

Compared with the cases reported in USA these six Japanese patients had different clinical features.

\section{Materials and Methods}

Sera for the test of insulin-receptor antibodies were collected from patients at institutions throughout Japan and from patients treated at the Diabetes Center, Tokyo Women's Medical College, from September 1975 to October 1979. Our criteria for the selection of patients were as follows: (1) Use of 80 I.U. or more of insulin without attaining satisfactory diabetes control. (2) An immunoreactive insulin (IRI) value of $50 \mu \mathrm{U} / \mathrm{ml}$ or over in the fasting state at the presence of decreased glucose tolerance. (3) Hypoglycemia of unknown origin.

We studied 70 serum samples from 61 patients; 31 for criterion 1, 20 for criterion 2 , and 10 for criterion 3 . Serum samples were also collected from 11 normal, healthy individuals and from six patients treated with insulin at our Diabetes Center and having insulinbound antibodies.

Insulin-bound antibodies were measured by the polyethylene glycol method (Desbuquois and Aurbach 1971) and IRI by radioimmunoassay (two-antibody method). When insulin antibodies were found to be positive, we measured IRI after extraction by Grodsky's ethyl alcohol method (Grodsky and Forsham 1960).

The ${ }^{125}$ I-insulin used was labeled in the Dainabot Ltd. (Tokyo) using the lactoperoxidase method (Miyachi et al. 1972). Specific ${ }^{125} \mathrm{I}$-insulin activity was 120 to $150 \mu \mathrm{Ci} / \mu \mathrm{g}$.

The test for insulin-receptor antibodies in the blood was done by a previously reported method (Omori and Hirata 1976).

In the direct method, $0.2 \mathrm{ml}$ of serum, $0.1 \mathrm{ml}$ of placental membrane solution $(2 \mathrm{mg} / \mathrm{ml}$ as protein concentration), and $0.1 \mathrm{ml}$ of ${ }^{12}{ }^{5} \mathrm{I}$-insulin $\left(10^{5} \mathrm{cpm}\right.$ or $\left.800 \mathrm{pg}\right)$ were serially added to $0.1 \mathrm{ml}$ of buffer $\left(10 \mathrm{mM} \mathrm{MgCl}_{2} 25 \mathrm{mM}\right.$ Tris $\mathrm{HCl}, \mathrm{pH} 7.4$ containing $0.1 \%$ bovine albumin), and the mixture was kept at $4^{\circ} \mathrm{C}$ overnight. Three $\mathrm{ml}$ of ice-cold buffer were then added to halt the reaction, the mixture was centrifuged at $3,000 \mathrm{rpm}$, and the supernatant was decanted. ${ }^{125} \mathrm{I}$-insulin in the precipitated membrane was then measured.

The preincubation method was done simultaneously by adding $0.2 \mathrm{ml}$ of patient serum and $0.1 \mathrm{ml}$ of $2 \mathrm{mg} / \mathrm{ml}$ membrane solution to $0.2 \mathrm{ml}$ of the buffer. The mixture was then kept in an incubator for $24 \mathrm{hr}$ at $4^{\circ} \mathrm{C}$. The supernatant was then decanted after centrifuging at $3,000 \mathrm{rpm}$ for $30 \mathrm{~min}$. The precipitated pellet was washed twice with ice-cold buffer, then $0.3 \mathrm{ml}$ buffer and $0.1 \mathrm{ml}$ of ${ }^{125} \mathrm{I}$-insulin $\left(10^{5} \mathrm{cpm}\right)$ were added. After overnight incubation at $4^{\circ} \mathrm{C}$, the binding of ${ }^{125} \mathrm{I}$-insulin to placental membrane was observed.

This binding was reduced $14 \%$ by the addition of $10 \mathrm{ng} / \mathrm{ml}(1 \mathrm{ng} /$ tube $)$ of unlabeled insulin. Since patient sera often contained high levels of IRI, the gel filtration method was used (Sephadex G-50 column $1 \times 20 \mathrm{~cm}, \mathrm{pH}$ 8.4) for separation. The protein and IRI fraction were isolated from $0.5 \mathrm{ml}$ to $0.8 \mathrm{ml}$ of patient sera. After freeze-drying, protein fractions were resolved into the same concentration as eluted serum, and the influence on ${ }^{125}$ I-insulin and membrane binding was observed using these fractions.

The immunoglobulin class of insulin-receptor antibodies was studied by adding ten volumes of antihuman IgG, IgA, and IgM sera (Behringwerke) to $0.02 \mathrm{ml}$ of patient serum (some variation existing due to the antibody titer of cases). The mixture was centrifuged at $3,000 \mathrm{rpm}$ for $30 \mathrm{~min}$ after overnight incubation at $4^{\circ} \mathrm{C} .100 \mu \mathrm{g} / 0.1 \mathrm{ml}$ of membrane was added to the supernatant thus obtained and the mixture was again incubated overnight at $4^{\circ} \mathrm{C}$. The membrane was rinsed, then $0.4 \mathrm{ml}$ of buffer and $0.1 \mathrm{ml}$ of ${ }^{125} \mathrm{I}$-insulin were added. 
Radioactive insulin binding to the membrane was observed after overnight incubation at $4^{\circ} \mathrm{C}$.

We also studied the influence of hyperlipemia and hyperproteinemia on binding using sera with a triglyceride value of 236 to $716 \mathrm{mg} / 100 \mathrm{ml}$ (338 \pm 168 , mean \pm s.D.).

Hyperproteinemia in the assay system was produced by adding $0.2 \mathrm{ml}$ of bovine serum albumin (BSA) solution containing a protein concentration of 2 to $12 \mathrm{~g} / 100 \mathrm{ml}$ to the incubation medium. The effect of ${ }^{125}$ I-insulin binding to the membrane was observed using direct and preincubation methods.

The binding ratio of radioactive insulin was changed by differently labeled insulin and differently prepared membrane. The control binding ratio obtained by sera from normal subjects was used as a comparison. Where fundamental examinations such as displacement curves were made, bound/total percent per se was expressed as an absolute value which we called the absolute binding rate, as opposed to the relative binding rate obtained by the comparison to controls. Insulin used for the study of displacement curves was Monocomponent procine insulin lot S 835158 produced by the Novo Company.

\section{Results}

\section{Influence of triglycerides and BSA on the binding of ${ }^{125}$ I-insulin and membrane}

When the binding rate in cases with normal triglyceride levels was taken as $100 \%$, a relative binding rate in all cases $(n=7)$ showed $101.0 \pm 5.17 \%$ (mean \pm S.D.).

Protein concentration in the medium obtained by adding $3 \mathrm{~g} / 100 \mathrm{ml}$ or less of BSA showed no effect in the direct method. A remarkable interference in binding was observed, however, with higher BSA concentrations.

Binding was not influenced by preincubation with highly concentrated BSA. Membranes were washed twice after treatment and incubated with ${ }^{125}$ I-insulin (Fig. 1). The same experiment was done twice.

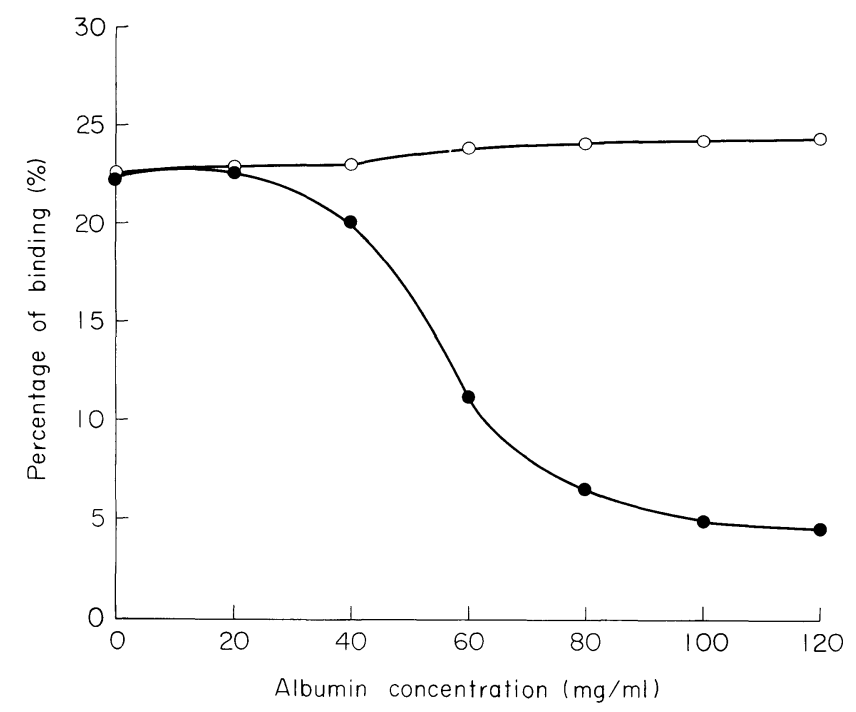

Fig. 1. Effect of albumin concentration on the binding of ${ }^{125} \mathrm{I}$-insulin with placental

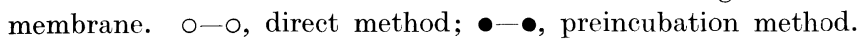


Influence of sera of patients and normal subjects on binding

Sera of normal subjects. No insulin-binding antibodies were observed in the serum samples of 11 normal subjects. Binding was examined by adding buffer instead of sera and was shown to be $31.5 \pm 1.2 \%$ (mean \pm s.D., $n=20$ ) of total added radioactive insulin. The effect of the sera was expressed by percentages of buffer control. The results were $97.9 \pm 3.6 \%$ (mean \pm s.D.) for the direct method and $101.8 \pm 4.6 \%$ for the preincubation method (Fig. 2).

Sera of insulin-treated diabetic patients. The sera of six patients under insulin therapy showed the existence of an insulin-binding antibody rate; the ability to bind radioactive insulin $(0.3 \mathrm{ng} / \mathrm{ml}$ final) was between $67.6 \%$ and $43.9 \%$, with a mean of $56.4 \%$. Binding was decreased in the direct method (Fig. 2). In the preincubation method, relative binding of ${ }^{125}$ I-insulin to membrane was $96.7 \% \pm$ $6.4 \%$.

Sera of 61 subjects. The direct method was applied to investigate insulinreceptor antibodies. Among the 61 cases examined, 26 showed binding of $80 \%$ or less. Eight of the 61 showed binding of less than $80 \%$ with the preincubation method (Fig. 2).

Of the eight subjects, two with binding rates of $74.4 \%$ and $47.2 \%$ did not reveal the suppressed binding when the incubation was done with gel-filtrated protein fractions, the binding being $95.0 \%$ and $98.3 \%$. This suggests that no substance was detected in the protein fractions of these two patients which impeded binding.

Since insulin-binding antibodies could not be proved in these two cases, it would appear that binding of ${ }^{125}$ I-insulin to the membrane was decreased due to the dilution of radioactive insulin by high concentrations of IRI in the blood, i.e., 320 $\mu \mathrm{U} / \mathrm{ml}$ and $11,720 \mu \mathrm{U} / \mathrm{ml}$.

The protein fraction from the remaining six cases indicated the following

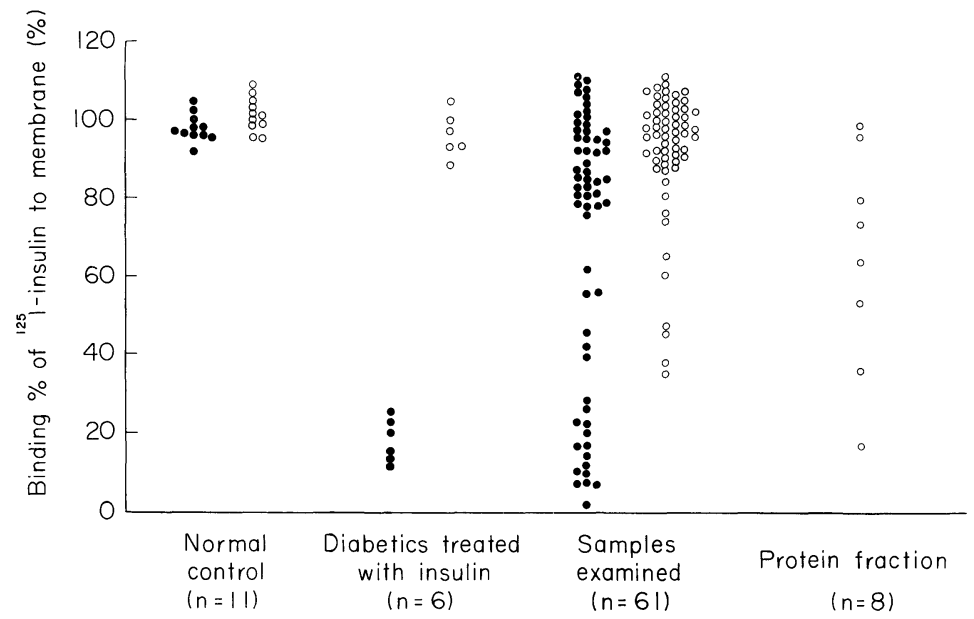

Fig. 2. Results of incubation with various sera. o, direct method; $\bullet$, preincubation method. 
TABLE 1. Six cases having insulin receptor antibodies among 61 cases

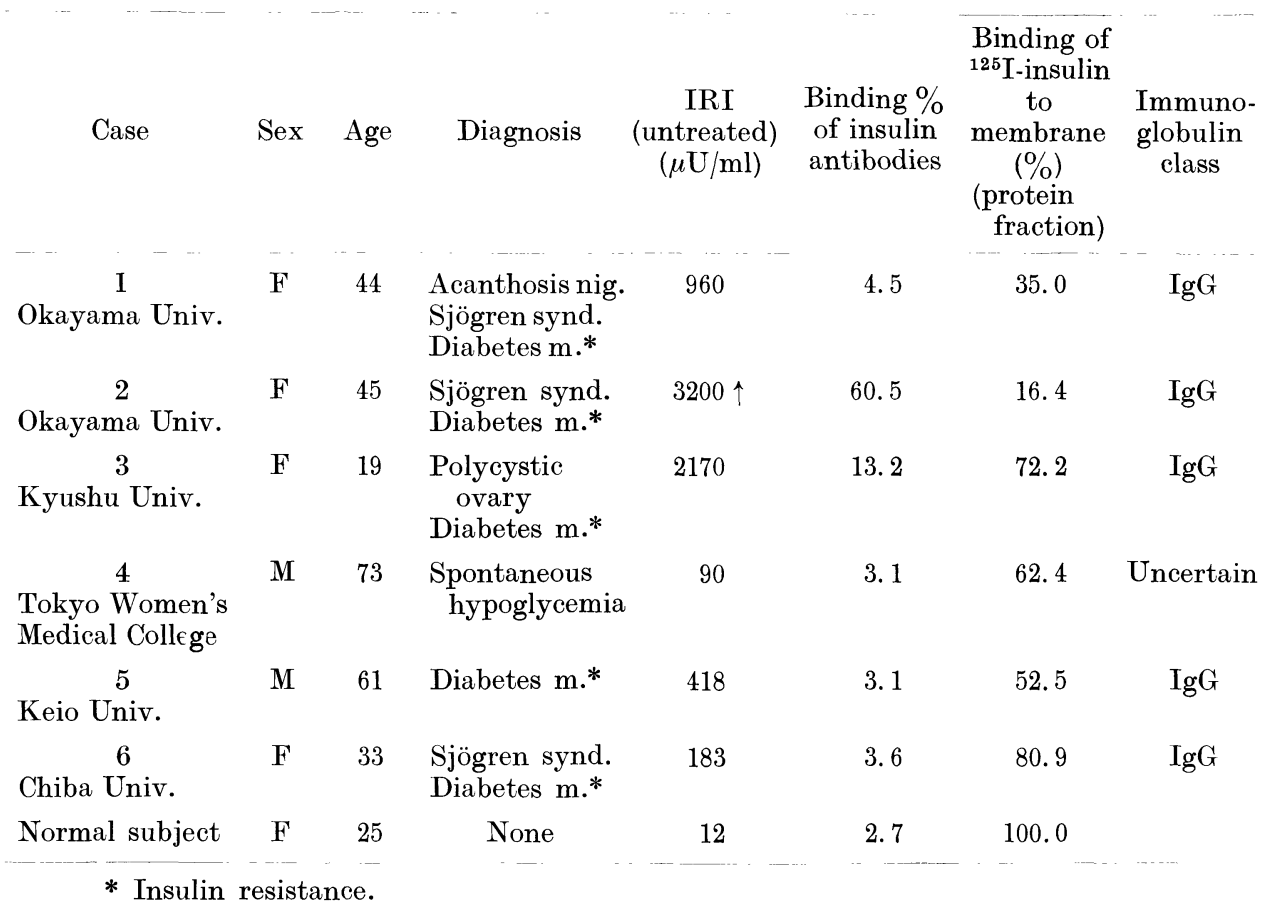

binding rates with the preincubation method: Case 1, 35.0\%; Case 2, 16.4\%; Case $3,72.2 \%$; Case 4, 62.4\%; Case 5, 52.5\%; and Case 6, 80.9\% (Fig. 2 and Table 1).

Sera from five lipoatrophic diabetics did not impede the binding.

\section{Effect of sera on insulin binding to the receptor}

Since sufficient amounts of sera from Cases 1, 5, and 6 were obtained, the effect of unlabeled insulin on the binding of ${ }^{125}$ I-insulin and membrane was studied.

The experiments were conducted at different times using different preparations of ${ }^{125}$ I-insulin and membrane. Elevation of unlabeled insulin concentration resulted in a distinct suppression of binding of radioactive insulin in experiments with normal control sera.

When $1 \mathrm{ng} / \mathrm{ml}$ of insulin was added, sera from Cases 1 and 5 inhibited binding to a level only one third of the controls. When the unlabeled insulin concentration was raised, the inhibitory effect of patient sera decreased (Figs. 3, 4)

In Case 6, suppression of binding by the addition of serum was relatively low as compared with Cases 1 and 5, but the inhibitory effect was significant (Fig. $5)$.

Based on these three displacement curves, a Scatchard plot analysis revealed a decreased receptor affinity in the presence of sera from Cases 1 and 6 . A decrease in receptor number as well as decreased affinity was observed in the experiment of Case 5 (Fig. 4). 


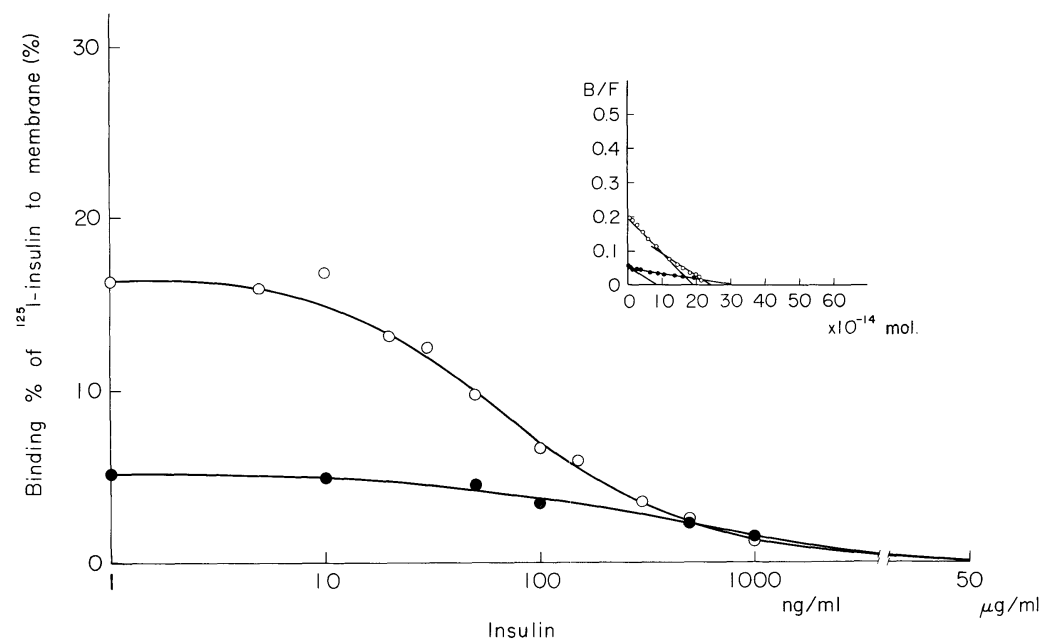

Fig. 3. Displacement curve and Scatchard plot of Case 1. ०-o, normal serum; patient serum.

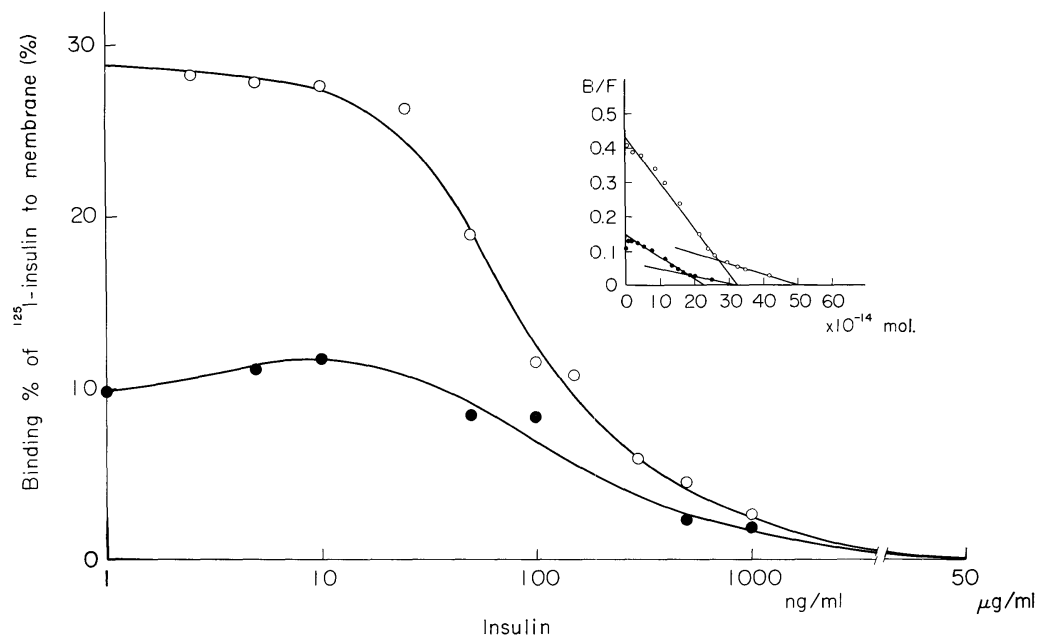

Fig. 4. Displacement curve and Scatchard plot of Case 5. ०-o, normal serum; --•, patient serum.

\section{Immunoglobulin class}

The immunoglobulin class of insulin-receptor antibody in the five out of six cases described above was studied using anti-human $\operatorname{IgG}, \operatorname{IgA}$, and $\operatorname{IgM}$ antisera. All cases tested (Cases 1, 2, 3, 5, and 6) had IgG class antibodies.

Determination of the immunoglobulin class could not be examined in the serum of Case 4 because of insufficient material.

Clinical findings in the six cases.

The six cases (Cases 1-6) consisted of two men (aged 61 and 73) and four 


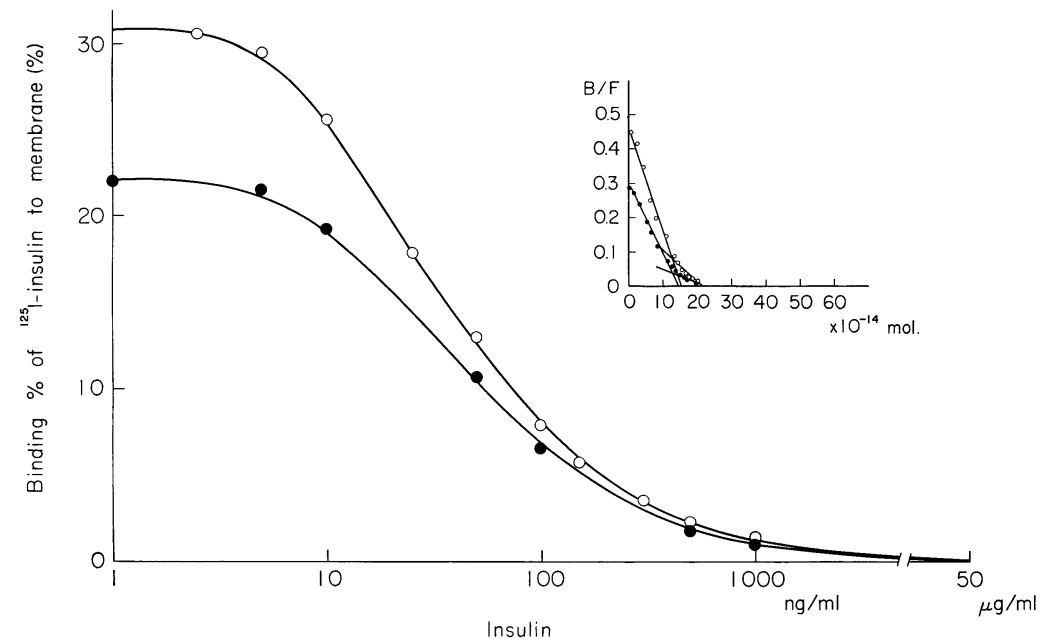

Fig. 5. Displacement curve and Scatchard plot of Case 6. ○-०, normal serum; patient serum.

TABLE 2. Course of inhibitory effect of patient serum

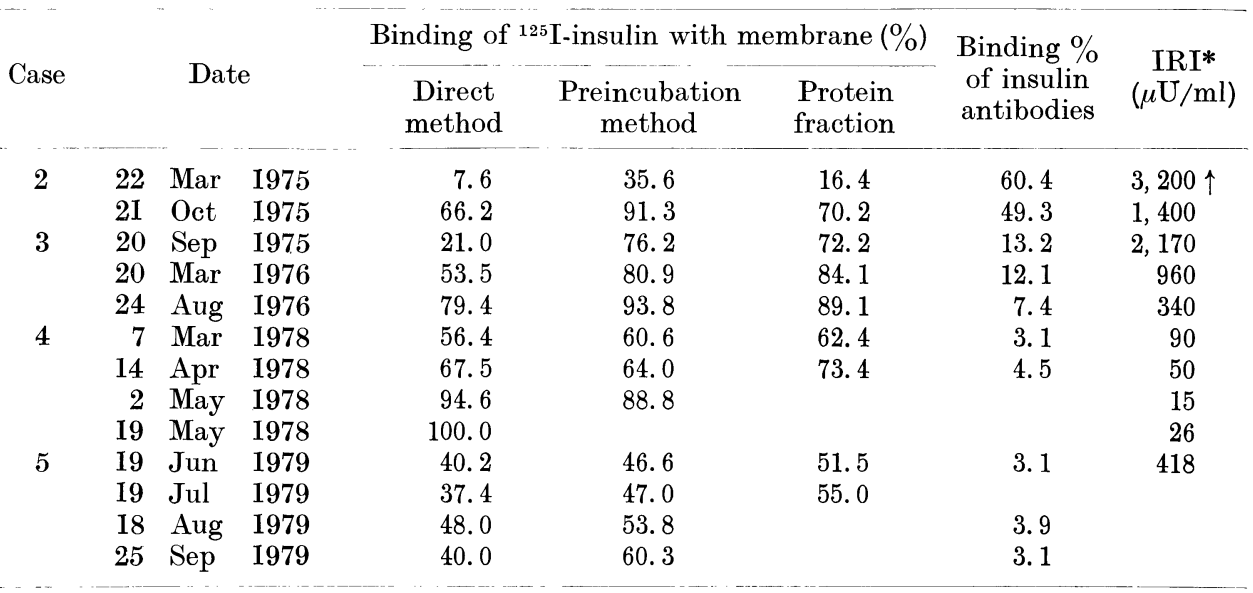

* IRI by routine radioimmunoassay of untreated serum.

women (aged 19 to 45 , with a mean of 35.2 years) (Table 1). Cases 1, 2, and 6 had diabetes accompanied by Sjögren syndrome, and Case 3 had diabetes and a polycystic ovary with insulin resistance. Cases 4 and 5 had diabetes with no apparent insulin resistance.

Case 4 had frequent, spontaneous hypoglycemia. Blood IRI, including that of Cases 1, 4, and 5 when insulin had not been administered, showed a high value. Only Cases 2 and 3 had insulin-binding antibodies.

Time course of inhibitory activity of ${ }^{125}$ I-insulin binding in patient sera

Table 2 shows ${ }^{125}$ I-insulin and membrane binding for Cases 2 to 5 . The 
activity of antibodies in Case 2 was decreased by steroid therapy (Kawanishi et al. 1977). A relative binding rate of $35.6 \%$ obtained with the preincubation method improved to $91.3 \%$ after seven months, demonstrating well the coincidence of the clinical course and the degree of impaired binding.

A relative binding of $76.2 \%$ in Case 3 increased to $93.8 \%$ after about one year, and the same result was obtained in a simultaneous experiment using a protein fraction. The remission of insulin resistance coincided well with the disappearance of impaired binding in this case (Wasada et al. 1979). In Case 4, the extent of impaired binding was proportional to the frequency of hypoglycemic attacks. The relative binding rate increased slowly to $56.4 \%, 67.5 \%, 94.6 \%$, and to $100 \%$ (normal) as the hypoglycemia disappeared (Takei et al. 1981).

In Case 5, neither insulin resistance nor hypoglycemic symptoms were observed after three months and good control with 40 units of insulin was obtained, but the binding was about $40 \%$ both in the initial test and after three months (Taniyama et al. 1979).

We also observed in this patient the same level of binding inhibition in the direct method and $60 \%$ of binding in the preincubation method at the end of three months.

\section{Discussion}

From studies on the placental insulin receptor (Omori 1976), we devised a method for detecting insulin-receptor antibodies, and found six insulin-receptor antibody-positive patients in Japan from 1975 to 1979 using this method.

Cases 1 and 2 were previously verified by Kahn et al. (Kibata et al. 1975; Kawanishi et al. 1977) as having insulin-receptor antibodies.

Our six patients, in contrast to those reported in the United States, did not always have insulin resistance and included three patients with Sjögren syndrome and one with acanthosis nigricans. They displayed a remarkably rapid disappearance of antibodies.

Immunoglobulin class in the serum of Case 4 could not be determined because of insufficient material, but he apparently had a substance in his blood which inhibited ${ }^{125}$ I-insulin and membrane binding. It seems highly probable that the inhibiting factor was insulin-receptor antibodies, since impaired binding in this case was observed even when the protein fraction was used as well as in the other five cases in which IgG was confirmed as an active component. In Case 4, despite GTT showing a diabetic type, hypoglycemia occurred frequently and insulin-receptor antibodies disappeared following remission of hypoglycemic symptoms.

The 37-year-old Type B Creole reported by Kahn et al. (1976) showed weakness at fasting or three to five hr after food ingestion, before the presence of insulin-receptor antibodies had been verified. With a diet, the weakness disappeared and blood sugar levels decreased to $36 \mathrm{mg} / 100 \mathrm{ml}$ after the 72 -hr-hunger test. Although the same insulinoma as in Kahn's patient was suspected in Case 4, tests were negative. 
Regarding the mechanism of hypoglycemia in cases where insulin-receptor antibodies exist, Kahn et al. (1977) and Kasuga et al. (1978) ascertained that the insulin-receptor antibody functions like insulin itself. Judging from follow-up studies of their patients, Flier et al. (1978) verified that hypoglycemia was caused by proliferation of the receptor in the presence of antibodies.

In Case 4, the mechanism operating in this hypoglycemia is uncertain, and it remains unclear whether it was caused by hyperinsulinemia originating in the presence of insulin-receptor antibodies or in the insulin-like function of these antibodies, receptor proliferation, or both.

The reports in the United States and our case findings suggest that in cases showing diabetes and high levels of IRI, the presence of insulin-receptor antibodies should be suspected. Insulin resistance is not, however, always observed as the cases in the United States indicate. The diabetics with insulin-receptor antibodies are not necessarily resistant to insulin and such patients may show spontaneous hypoglycemia alone.

The present studies suggest that the presence of insulin-receptor antibodies would probably be verified not only in insulin-resistant diabetes but also in different types of diabetes of a wider scope.

Results of analysis by Scatchard plot in Cases 1, 5, and 6 show that insulinreceptor antibodies are not monoclonal antibodies, consistent with data of Flier et al. (1977).

Flier et al. (1978), seeking to detect insulin-receptor antibodies, vigorously investigated cases of juvenile diabetes, adult diabetes, obese diabetes, severe insulin allergy, Pima Indian diabetes, lipoatrophic diabetes, exophthalmic goiter, myasthenia gravis, Sjögren syndrome, and other autoimmune diseases. No new patients with antibodies were discovered, however, although 14 patients with Type $\mathrm{B}$ insulin-receptor antibodies were found.

The fact that several blacks were included in these 14 cases and that six cases with such antibodies could be detected in our examinations among 61 cases from various areas in Japan may suggest a racially-based difference in the mechanism of antibody generation, as indicated also by the high incidence of insulin autoimmune syndrome in Japan.

\section{Acknowledgments}

We wish to express our gratitude to the following physicians for providing us with sera from their interesting patients: M. Kibata, Second Department, and K. Kawanishi, Third Department, Okayama University School of Medicine; T. Wasada, Third Department, Kyushu University School of Medicine; K. Kataoka and M. Taniyama, Keio University School of Medicine; K. Hirose, First Department, Chiba University School of Medicine; and M. Okuyama, Third Department, Gifu University School of Medicine, who sent us lipoatrophic diabetes test materials.

\section{References}

1) Desbuquois, S. \& Aurbach, G.D. (1971) Use of polyethylene glycol to separate free 
and antibody bound peptide hormone in radioimmunoassay. J. clin. Endocr., 33, 732738.

2) Flier, J.S., Kahn, C.R., Jarrett, D.S. \& Roth, J. (1977) Auto-antibodies to the insulin receptor: Effects on the insulin-receptor interaction in IM-9 lymphocytes. J. clin. Invest., 60, 784-794.

3) Flier, J.S., Bar, R.S., Muggeo, M., Kahn, C.R., Roth, J. \& Gordon, P. (1978) The evolving clinical course of patients with insulin receptor auto-antibodies: Spontaneous remission or receptor proliferation with hypoglycemia J. clin. Endocr. Metab., 47, 985995.

4) Grodsky, G.H. \& Forsham, P.H. (1960) An immunochemical assay of total extractable insulin in man. J. clin. Invest., 30, 1070-1079.

5) Kahn, C.R., Flier, J.S., Bar, R.S., Archer, J.A., Gordon, P., Martin, M.M. \& Roth, J. (1976) The syndrome of insulin resistance and acanthosis nigricans: Insulin receptor disorders in man. New Engl. J. Med., 294, 739-745.

6) Kahn, C.R., Baird, K., Flier, J.S. \& Jarrett, D.S. (1977) Effects of auto-antibodies to the insulin receptor on isolated adipocytes: Studies of insulin binding and insulin action. J. clin. Invest., 60, 1094-1106.

7) Kasuga, M., Akanuma, Y., Tsushima, T., Iwamoto, Y., Kosaka, K., Kibata, M. \& Kawanishi, K. (1978) Effects of anti-insulin receptor antibodies on the metabolism of human adipocytes. Diabetes, 27, 938-945.

8) Kawanishi, K., Kawamura, K., Nishina, Y., Goto, A., Okada, S., Ishida, T., Ofuji, T., Kahn, C.R. \& Flier, J.S. (1977) Successful immunosuppressive therapy in insulin resistant diabetes caused by anti-insulin receptor autoantibodies. J. clin. Endocr. Metab., 44, 15-21.

9) Kibata, M., Hiramatsu, K., Shimizu, Y., Fuchimoto, M., Sasaki, M., Shimono, M., Miyake, K., Flier, J.S. \& Kahn, C.R. (1975) "Insulin receptor antibody" found in a case of Sjögren syndrome associated with extreme insulin resistance diabetes. Proc. Symp. Chem. Physiol. Path, 15, 58-63. (Japanese)

10) Miyachi, Y., Vaitukaitis, L., Nieshlag, E. \& Lipsett, M.B. (1972) Enzymatic radioiodination of gonadotropin. J. clin. Endocr. Metab., 34, 23-28.

11) Omori, Y. (1976) Insulin degradation by human placental membranes. J. Jap. Diab. Soc., 19, 360-368.

12) Omori, Y. \& Hirata, Y. (1976) Studies on the detection of anti-insulin receptor antibodies in the serum by hunan placental membrane. J. Jap. Diab. Soc., 19, $833-838$.

13) Takei, M., Nishikawa, A., Omori, Y. \& Hirata, Y. (1981) A case of spontaneous hypoglycemia associated with auto-antibodies to insulin receptors. J. Jap. Diab. Soc., 24, 395-404.

14) Taniyama, M., Kiyotaki, M., Ishizawa, S., Maruyama, H., Katayama, K., Matsuki, S., Omori, Y. \& Hirata, Y. (1979) A case of diabetes mellitus having anti-insulin receptor antibodies. J. Jap. Endocr., 55, Suppl. 1150.

15) Wasada, T., Sakimoto, T., Aso, Y., Kato, K., Ibayashi, H. \& Omori, Y. (1979) A case of insulin-resistant diabetes with possible antibodies to insulin receptors. Endocr. Jap., 26, 19-26. 